\title{
"I have written the things which I did hear, see, tasted and handled:" Selfhood and Voice in Katherine Evans' and Sarah Cheevers' A Short Relation of Their Sufferings (1662)
}

\author{
Carme Font Paz \\ Universitat Autònoma de Barcelona
}

\begin{abstract}
This article analyses the representation of selfhood in a major Quaker autobiography, A Short Relation (1662), written by Katharine Evans and Sarah Cheevers; the analysis will try to assess, through a detailed discussion of the voices in the text, the dynamic female selfhood that emerges from it and its main constitutive elements. Secondly, and with the help of Evans' and Cheevers' private correspondence, the article contextualises this notion of selfhood in the social space of early Quakerism in order to assess the extent to which it was informed by the Quaker emphasis on gender equality before God and women's relationship to the divine. At the same time, this analysis invites us to regard $A$ Short Relation as a major early modern autobiography that may be particularly challenging to presentday Gender Studies.
\end{abstract}

KEYWORDS: Quakerism, early modern women writing, autobiography, gender, prophetic writing.

\section{Introduction}

To a certain extent, research is still catching up with the multiplicity and variety of early modern autobiographical writings by women. This is particularly true in the case of religious writings: even though research in this area has multiplied over the last two decades, the challenges posed by these texts keep compelling us to reassess our preconceptions of what "women's writing" is, and of what it has been over history. No doubt this is as a result of the 
enormous variety of these materials: along with the general impulse given to writing by the spread of Protestantism, there were multiple (and often incompatible) traditions of belief that developed in Britain during the sixteenth and seventeenth centuries; the very act of writing revealed diverse meanings and connotations in each of these traditions, and this applies to the concept of "self" expressed in autobiographical texts too. As a consequence, it is difficult for scholars to generalise: each tradition of writing seems to require a different methodological approach and perspective from which to appreciate and understand it. Hilary Hinds in her thorough study God's Englishwomen presents a middle ground in the theoretical approach to sectarian writing in the early modern period by acknowledging the importance of both historical contextualization and a literary analysis which allows its inclusion in a long line of women's writing (Hinds 1996:14).

Writings by early Quaker women seem to be particularly resistant to our modern (or post-modern) concepts of woman's writing; as Suzanne Trill puts it, any attempt to search "for a uniquely female voice in these texts runs counter to the Quaker's aspiration to merge the self with God" (1997:45). Certainly, most of the early texts written by Quaker women invite the reader to seek "the Light," the illumination of the self which can make it one with the Holy Spirit; any other aim or purpose within them is always subordinated to that primary intention. The writings of Margaret Fell (1660), Katharine Evans (1662), or Hester Biddle (1660), for instance, were not essentially concerned with the condition of women, but with the affirmation of the will of God to expand the community of believers. On the other hand, and from a strictly theological perspective, Quakers believed in an equal access to "the Light" both for men and women, and because of this female authors such as Fell or Biddle were able to speak with a strong sense of authority: in theological terms, their gender was no obstacle to becoming receptacles of the voice and authority of God.

Women were particularly suited to adopting this prophetic role, since their biological construct as "vessels" and "recipients" enabled them to act as perfect channels for God's speech. Phyllis Mack supports this view by remarking that characterising the female "visionary" as an empty vessel cannot be easily termed "misogyny." In fact, she reminds us that: 
The defects of rationality and the attuned intuition of visionary women were actually viewed with respect, even envy, by those philosophers who felt alienated from God by their compulsive, prideful reliance on the power of their own reason. Indeed, in this respect all women had a clear spiritual advantage over men, for the static resulting from their weak and intermittent surges of intellectual energy was less likely to interfere with their capacity to act as receptors for the divine. (Mack 1994:33)

This emotional quality of women which makes them receptive and intuitive channels is appropriate for the expression of spiritual values. Prophetic writing may thus appear as intimately related with the feminine because it requires from the prophet an emptiness, a passivity, which was necessary to prophesise.

Yet, as readers of early modern literature we cannot forget that the simple fact of writing and speaking in public was, for these women, fraught with difficulties and dangers. ${ }^{1}$ Even when early Quaker texts by women do not make a point of gender distinctions, that difference is nevertheless inscribed in them, especially in the most directly autobiographical materials. It may not appear in the voice of the women authors themselves, but certainly in the voices of their adversaries. Catie Gill articulates this view by considering these texts as recipients of the anxieties that surrounded women's public expression of faith, and argues that "the voice these women claim when writing about punishment, then, is often directly or indirectly a response to others' ineffective attempts to silence them" (Gill 2009:259). Gender differences are indeed present in the texts by Margaret Fell or Katharine Evans, even if they are not recognised as such by these authors: they are presented, rather, as instances of the corrupt structures of the Fallen world, as examples of the power of sin against which the believers have to stand as testimonies of faith. Early Quaker literature by women thus offers a unique dialectic which can be taken as a challenge to Gender Studies and its analytic tools: in these texts, the egalitarian discourse of Quakerism clashes with the patriarchal structures of seventeenth-century society; but

\footnotetext{
${ }^{1}$ John Ray Knott argues that Quakers were the religious community which, soon after the Restoration, and despite Charles II's moves towards toleration, suffered most from the backlash against sects, with the passing of the Quaker Act instituting penalties for refusing to take the oath of allegiance and with the close surveillance of the printing presses. Knott notes that Quakers both suffered most and as a sect did more to record and publicize their suffering than any other group (1993:216-217).
} 
even as these clashes are registered, they seem not to affect the sense of identity of their authors, who, as we will see in this article, remain firmly identified with the will of God and rarely acknowledge or rebuke the validity of social differences.

\section{Aims and Methodology}

A Short Relation by Katherine Evans and Sarah Cheevers (1662) belongs to the tradition of autobiographical narratives written by religious dissenters which would become quite popular in the $1660 \mathrm{~s}$ and 1670 . There is now an increasingly broad scholarly consensus that these modes of autobiographic narration became especially important in the Restoration (Hinds 1996; Wiseman 1992; Feroli 2006; Gill 2005), when the links between the different dissenting communities, in England and abroad, had to be strategically reinforced. A Short Relation therefore operates, like other works of its kind, on two different and complementary levels: as an account of individual subjectivity (through the voice of Katharine Evans that predominates in the text) and as a product for religious consumption, meant to strengthen the ideology and the practices of the community it addresses. This interplay between the voice of the individual and its intended audience (the religious group) creates a dialectic that is specifically characteristic of early modern Quaker culture, and of the ways in which female authority could be established within it. A Short Relation, nevertheless, goes much further, since the text manages to present a viable model for the configuration of selfhood that is representative of the flexibility and dynamism of seventeenth-century religious female writing.

Rather than focusing on the narrative content of $A$ Short Relation, this article will pay attention to the articulation of forms of subjectivity within the text. Throughout the narrative, we not only find a single individual perspective (the "I" of Katherine Evans) but also a surprising variety of voices that constantly interrelate, address and interrogate one another. This plurality of voices in the same text is what gives a unique quality to A Short Relation, as the voice of Katherine Evans, her perspective and her interpretation of her experience are actively generated, created, in this multi-vocal textual space. This article, therefore, offers a detailed analysis of the literary 
construction of self and subjectivity within a text that is dynamic and multiform, yet fully coherent in its message and purpose.

What makes A Short Relation stand out among other autobiographical narratives produced in the same context is the dynamic interplay that is generated, all through the text, between a wide variety of voices: the voices of the Quaker women protagonists, those of their Catholic opponents, and even that of the Spirit, which makes itself openly present in the text, differentiating itself from the rest of speakers. The following pages explore this rich multi-vocality, establishing the way it relates to the sense of selfhood and religious identity presented in the text, examining the extent to which it contributes to (or detracts from) the prophetic authority claimed by Evans and Cheevers. Catie Gill has acknowledged the centrality of this multi-vocality pointing out that "Quaker women's speech patterns are of particular importance in understanding the textual representation of their suffering" (Gill 2005:259).

Due to their significance, Mikhail Bakhtin's theory of dialogism and some of its corresponding terminology will be used to discuss the various voices and accents in the text. My intention in doing this is not to postulate the Bakhtinian model as necessarily being the most appropriate for the analysis of early modern autobiographies by women; rather, Bakhtinian categories will be employed as useful tools for a better understanding of the stylistic levels of $A$ Short Relation. The Russian theorist concentrated especially on the development of stylistic plurality and variety in literary developments from the Latin Middle Ages to the creation of the modern novel; the early modern period, with its many moments of transition between different forms of religious culture, and between the sacred and secular worlds, was repeatedly presented by him as a historical moment of decisive importance in the creation of literary models that were dynamic, dialectical and multiform, in contrast to their medieval predecessors -models that, in themselves, could be seen as belonging to the "prehistory of novelistic discourse" (Bakhtin 2996). The following section specifies the Bakhtinian categories that are most useful to the present analysis; suffice to say, for now, that these address some of the questions that $A$ Short Relation continues to pose today: How is subjectivity created in this text? How do its multiple voices relate to each other? How do these factors sustain prophetic authority, and is that authority gendered? 


\section{Prophetic Speech in the Context of Quaker Women's Writing}

Although A Short Relation cannot be regarded as a conventional autobiography, it nevertheless shares distinctive features with both prophetic writing and the autobiographical genre. Like thousands of women in the mid-seventeenth century, Evans and Cheevers were middle-class housewives who had received only the basic rudiments of education. Yet their involvement in the Quaker community empowered them in a particular way: it offered them direct, immediate access to the word of God and to the presence of the Spirit. In this regard, several scholars have noted the importance of Quaker autobiographical texts, in particular those written in captivity, in the moulding of a sense of community. For Catherine Gray, Quakers were adept in forging bonding relationships across and beyond geographical borders, to the extent that women draw on their private spheres in times of stress, prosecution or incarceration in order to ground their counterpublic activities:

A Short Relation thus depicts two women at the centre of a wider circle, itself figured by the kind of intimate language of family and friendship. They refer to fellow Quakers as "Friends," "Brethen and Sisters," and "Nursing Mothers of Israel." The intensity of the women's relationship inflects their affiliation with Baker in particular, who is presented as an intercessor on their behalf, an ecstatic reader of their manuscripts and another spouse. (Gray 2007:187)

Often, the proximity of sharing the same cause with other fellow members becomes the stimulus for engaging with ecstasy or for uttering prophetic speech in which the voice of the author in prison and the words of the Bible merge in a single purpose and discourse:

The Lord (who alone is our Life and Redeemer) moved our dear Brother to offer his own body to redeem ours, but it would not be received; then he offered to lay down his own dear and precious life for our liberty: Greater love can no man have, than to lay down his life for his Friend; the Lord will restore it into his bosom double; his service can never be blotted out; his Name is called Daniel Baker; his outward being is near $\mathfrak{Z}$ ondon, right dear and precious heart he is: The blessing, strength, and power of the Almighty be upon him and his, and overshadow them for ever, 
Amen. Greater comfort could never be administred to us in our conditions. (Evans and Cheevers 1662:62)

Evans and Cheevers explain how the Lord moved Daniel Baker to offer himself as a prisoner in exchange for the two women. Even the practical act of offering oneself for incarceration becomes an object of divine intervention. Their speech is prophetic not because the authors foresee the future or warn their leaders of imminent doom, but because their entire writing is coated with a spiritual meaning which Evans and Cheevers understand and relay to the world in writing. ${ }^{2}$ The sense of bonding reinforces the authority of prophetic speech and the voices of women authors within their communities. When they write "his Name is called Daniel Baker; his outward being is near London, right dear and precious heart he is: The blessing, strength, and power of the Almighty be upon him and his," they are making a distinction between Baker's outward body (the physicality of his body, which lives in London) and his spirit or heart, which is with them. Leaving aside the Antinomian and mystical Pantheist reverberations of the distinction between soul and body (Punshon 2006:41), Evans and Cheevers here are extending the geographical borders of their community and strengthening the prophetic character of their own selves and their salvic mission: suffering is, for these women, a form of bonding and articulating their prophetic message beyond the prison walls. Patricia Crawford argues in this regard that:

Quakerism offered transcendence. It was a mystical and ecstatic religion. Inspiration from the Holy Spirit moved the believer away from anthropomorphic conceptions of God. Women could seek to transcend both class and gender. They could refuse social deference, bowing only to the Lord, and they could, by working through their female nature, as they understood it, be at one with the divine, where difference of sex was immaterial. (Crawford 1993:180)

In other words, their identity (and emphasis) as women talking to God was less important for Evans and Cheevers than the fact that they, as individuals, were giving themselves up to the will of God. If we take Quaker women's writing as representative of the emergence of female voice and selfhood in literature, we realise that a basic

\footnotetext{
${ }^{2}$ Diane Purkiss has defined prophecy as "any utterance produced by God through human agency" (1992:139).
} 
notion of individuality had to appear before any kind of gender identity could develop. Elspeth Graham qualifies this view by saying that "autobiography and individualism both imply some sort of dialectic between the agency of the individual and awareness of the self, or self-consciousness" (Graham 2000:197). However, the early modern concept of the self was quite different from our contemporary post-modern notions of individuality; in the English society of the Renaissance and the Restoration, the self was not defined in terms of unconscious desires, even less in terms of physical appetites or urges. For Quakers, in particular, the self was closely defined by "conscience", seen as a fragment, or a part, of universal truth: it was God's own voice embedded in the self, a voice to which they also referred as "the light" or "the seed." The act of prophesying, on the other hand, had nothing to do with foreseeing the future: it had to do with transmitting the words and the will of God, engaging in communication with Him when the individual consciousness was prepared for it.

\section{The Voices in the Text}

Katherine Evans (c.1618-1692), from Inglesbatch near Bath, and Sarah Cheevers (c.1608-1664), from Slaughterford, Wiltshire, were travelling companions in the ministry, itinerant Quakers who preached their message throughout England and in other countries. Evans and Cheevers had been among the earliest Quaker missionaries to Scotland in 1653, and they were used to encountering opposition to their preaching activities. In 1655 Evans was banished from the Isle of Wight after enduring harsh insults and "many abuses from the rude people there" (Besse 1753:2.495), and later that year she was put on trial along with eight other Friends (including her fellow Quaker leader James Nayler) for visiting Quaker prisoners; this resulted in her imprisonment in Exeter in 1655. Despite all their various exploits and intense life, neither Evans nor Cheevers left a full autobiographical account of their conversion to Quakerism; all the available biographical data on these two women comes from $A$ Short Relation (1662) and from a much later work, Joseph Besse's A Collection of the Sufferings of the People Called Quakers (1753), a massive two-volume account of early Quaker preaching. Stefano Villani's entries on Evans and Cheevers in the Oxford Dictionary of National Biography, drawing on sources from the 
Archivio Segreto Vaticano and the Archivum Inquisitionis Melitensis in Malta, provide some further details on their prosecution and eventual release.

When in 1658 Evans and Cheevers undertook a sea voyage from England to Alexandria, Egypt, they knew that they were leaving behind their respective husbands and children (Evans' husband, John, was also a Quaker minister) to embark on a dangerous journey, yet there is no evidence that this was perceived by them as a challenge to their family life and status. On the contrary, as their private writings show, their strong commitment to Quakerism did not imply for them a denial of their status as beloved wives and mothers. ${ }^{3}$ The two women were bound for Alexandria, but when their ship put in at Valletta, Malta, they began to preach and distribute Quaker literature written in English and Spanish in the streets, even going so far as to interrupt a mass, which caused the intervention of the authorities. ${ }^{4}$ After being arrested, the two women were handed over to the English consul for safe-keeping, but the chief Inquisitor of the island ordered that they be moved to a prison, where they remained from April 1659 until July 1662. Several unsuccessful attempts were made by fellow Friends (notably George Fox) to convince the prison authorities of their innocence, and to secure their release. Among their most prominent visitors was also the Quaker leader Daniel Baker, who asked for their release and who, "in line with common Quaker practice, offered himself as a substitute prisoner" (Booy 2004:27); although his efforts to win their freedom were unsuccessful, Baker left Malta carrying several documents written by them and, back in London, he published the first version of their prison narrative, A Short Relation. Evans and Cheevers were finally released in September 1662, and reached England later that year. A Short Relation thus belongs to the subgenre of "prison narratives," an autobiographical form that together with death-bed testimonies and conversion narratives- was particularly cultivated by Quaker women, more than in other dissenter religious groups. Unlike the conventional "captivity narrative," which normally presents a story of people captured by

\footnotetext{
${ }^{3}$ In the letters addressed to their husbands, we typically find expressions such as: "My most dear and faithful Husband, Friend, and Brother" (Evans 1663:69), or "My Love, my life is given up to serve the Living God" (Cheevers 1663:73).

${ }^{4}$ At that time, Malta was ruled by the Roman Catholic Knights of Saint John.
} 
"uncivilized" enemies, "prison narratives" imply a spiritual renewal (Gill 2009).

Given the specificity of $A$ Short Relation, a few of the categories introduced by Bakhtin can be helpful when approaching a text that is as heterogeneous as this one. According to Bakhtin, the prehistory of novelistic discourse in the West was characterised by the presence of several "extremely heterogeneous factors at work;" among these were the presence of irreverent laughter, the relativisation of the authorial voice and, most especially, heteroglossia, the rich interpenetration and dynamic interaction of multiple and contrary voices within the same text. As Bakhtin observed, "the interanimation of languages made possible the genre of the novel" (Bakhtin 1981:78), and this remained the major characteristic of the novel until the nineteenth century, when it culminated in the great polyphonic works of Dickens and Dostoevsky. The defining characteristic of heteroglossia is, precisely, this rich and powerful interpenetration and inter-fertilisation of different voices and styles, which ultimately frustrates any possibility of establishing a hierarchy among them:

Different linguistic and stylistic forms may be said to belong to different systems of language [...] If we were to abolish all the intonational quotation marks, all the divisions into voices and styles, all the various gaps between the represented "languages" and the direct authorial discourse, then we would get only a conglomeration of linguistic and stylistic forms. (Bakhtin 1981:174)

Against the essential feature of heteroglossia, and in contrast to it, Bakhtin sets the concept of "monology" or monological discourse, which corresponds to any form of discourse or text that is controlled by a single, over-arching perspective. In such discourse, narrative is ultimately subordinated to a dominant voice or perspective which controls it, stabilising its meaning and interpretation; thus, monological uses of language tend to favour univocal world-views and to reduce the presence of different accents within them. As Michael Holquist suggests in his commentary, these uses of language tend to "privilege oneness: the more powerful the ideology, the more totalitarian (monologic) will be the claims of its language" (Holquist 1990:51-53). In this sense, it is worth paying attention to the articulation of the various voices in A Short Relation and whether it leads to ideological and stylistic openness 
(heteroglossia) or to a sense of dogmatic and formal closure (monoglossia).

Before concentrating on the text itself and its formal peculiarities, however, it is necessary to observe that the work that we designate $A$ Short Relation, is itself presented to the readership (that is, both to the Quaker community and to the occasional reader) by an external element: the introduction written by Daniel Baker. The presence of Baker's text can be read as a protocol that guarantees the truth of the experience narrated in the tract, and at the same time introduces a principle of extrinsic authority validating the voice of the women. Baker's voice disappears entirely after his preface, and is replaced by the autobiographical narrative by both women till the end; nevertheless, we must be aware of its strategic value. It is a male voice and an editorial voice, and these two factors legitimise, to a certain extent, the seriousness and credibility of the text that comes after it; such a legitimation would be probably less important for the Quaker community itself, but it was indispensable in a printed work that was meant to circulate beyond the limits of the religious community it overtly addressed. But Baker's voice is an element of initial mediation, not of constant tutelage: it vanishes as soon as the narrative authored by Evans and Cheevers begins.

Thus $A$ Short Relation begins with a six-page preface by Daniel Baker, "An Epistle to the Readers," which is also printed in the second edition of the text, A True Account of the Great Tryals and Cruel Sufferings (1663); it is followed by a brief "Salutation" by Baker, too, which is considerably pruned in the 1663 edition. The 1662 edition is printed in quarto, while the 1663 edition is in octavo. The account by Evans and Cheevers proper opens with a direct address from the speaking voice to its potential readers, in a gesture which already clarifies, in its use of Scriptural formulae, its religious tenor:

O Ye Eternal and Blessed ones, whose dwelling is on high, in the fulness of all Beauty and Brightness, Glory and everlasting Joy, Happiness and Peace for evermore; We who are poor sufferers for the Seed of God, in the Covenant of Light, Life, and Truth, do dearly salute and embrace you all, according to our measures, Blessing and honour and Glory be given to our Lord God for ever, and all who know him, who hath counted us worthy, and hath chosen us among his faithfull ones, to bear his name and to witness forth his truth, before the high and mighty men of the earth. (Evans and Cheevers 1662:1) 
The speaking voice begins by demarcating the readership it is addressing to: those whose dwelling is "on high," the members of a community (the Quakers) that aims for "everlasting joy," to whom a salute and an embrace are sent, "according to our measures." But this initial gesture is not carried out by one person alone: from the start, the narrative voice speaks in the first-person plural, a " $w e$ " that includes both Katharine Evans and Sarah Cheevers, "poor sufferers for the seed of God." This early reference to themselves as suffering for the "seed" also implies an insistence on their role as preachers, as those who are directly involved in spreading and disseminating the sacred word, in the work of fertilising the earth with the Spirit. After this initial welcoming gesture (in itself typical of Quaker literature), the text immediately acquires a more narrative quality:

The Lord did give us a prosperous journey hither, and when we came to Legorne, we were refreshed with friends [who were there before us] and they did get a passage for us (and lodging) but as soon as we heard of the Vessel, we did feel our service. So we went into the City in the living power of the Lord, and there many tender hearts did visit us, to their comfort, and our joy. The little time we staid there we gave some of our Books and one Paper: so, journeying towards Alexandria, the Captain told us that Malta was in the way, and he must put in there a small time. But, before we came there, our burthen was so heavy, that I was made to cry out (saying): Oh, we have a dreadful cup to drink at that place! (Evans and Cheevers 1662:1)

The missionary activity of the two women starts at Livorno ("Leghorn"), and part of that activity is identified as the distribution of printed material, which will afterwards be the source of their trouble and used as proof against them by the inquisitors. In terms of style, there is a particularly telling moment in this section: as the ship arrives at Malta, Evans' voice differentiates itself, for the first time, from the dominant "we", and there is a first hint of an individual perspective in the text ("I was made to cry out, saying: 'Oh, we shall have a dreadful cup to drink!'”) It is surely no coincidence that this use of the first-person singular pronoun should appear in an anticipation of suffering, nor that it should introduce a reference to Scripture (evoking Christ's own words at Gethsemane, before his Passion). Evans' sense of individual subjectivity is not constructed in a void, but against external opposition; it does not appear as the spontaneous expression of an isolated self, but as a voice that is strongly informed by the accents and the language of Scripture. 
The text goes on to detail how several storms slowed the women's progress towards Malta (as in anticipation of oncoming disasters), and how, upon their arrival, they were received by the English consul, who required from them a complete account of their mission. At this point, of course, the two women do not fail to remember that Saint Paul "suffered shipwrack" on an island: the identification with Paul will also be a recurring feature of their selfdefinition, and a source of consolation in their troubles. These start soon enough; having entered a church adjoining a monastery, they refuse to bow before the altar, a gesture that immediately identifies them as heretics in the eyes of the local community. It is at this point that the Inquisition intervenes:

The inquisitors sent for us, and when we came before them, they asked our Names, and the Names of our Husbands, and the Names of our Fathers and Mothers, and how many children we had, and they asked, wherefore we came into that Countrey? [...] The next day they came again, and called for us, and we came; but they would examine us apart, and called Sarah, and they asked, Whether she was a true Catholick? She said, that she was a true Christian that worshippeth God in Spirit and in truth; and they proffered her the Crucifix, and would have had her sware that she would speak the truth; and she said, she should speak the truth, but she would not swear, for Christ commanded her not to swear, saying, Swear not at all. (Evans and Cheevers 1662:4)

In this passage, it is the voice of Sarah Cheevers that is singularised and set apart: but, since the text is written by Evans, Cheevers' voice is reported externally, with her perspective being distinguished from the dominant one (Evans') through the use of the third-person singular pronoun ("She said that she was a true Christian"). It is also important to observe that, in the 1662 edition, the language of the inquisitors is physically distinguished from that of the two women through the very typography: their voices are reproduced in italics, while the voices of Evans and Cheevers appeared in unmarked roman type. The very external appearance of the text, its material presentation, seems to emphasise the ongoing contrast between the different perspectives, and different worldviews, taking place within it.

The second occasion we hear Evans' individualised voice occurs immediately afterwards, and it is also caused by her being interrogated separately (as Sarah Cheevers was before her) at the 
hands of the inquisitors. The theme of this interrogation is, initially, the worship of the crucifix, though the exchange quickly turns into a debate on the authority of human institutions:

Two dayes later they came again, and called for me, and offered me the Crucifix, and told me that the Magistrate commanded me to Swear by it, that I would speak the truth. And I told them that I would speak the truth, for I was a Witness for God; but I should not swear, for a greater than the Magistrate, saith, Swear not at all, but let your yea be yea, and your nay be nay [...] But said they, You must obey the justice, and he commandeth you to swear. I said, I should obey Justice, but if I should swear, I should do an unjust thing, for (the just) Christ saith, swear not at all. (Evans and Cheevers 1662:45)

The first-person singular pronoun tends to appear in the text when the context forces it to be differentiated from the communal "we"; it is only then that Evans speaks as an individual. And it is especially important to observe that, when she does so, her voice is sustained firmly by Scripture and by the guidance of Christ: it is from these sources that she derives her strength and sense of selfhood, for she is only, in her own words, "a witness for God." It is this role of witness that allows her to speak individually and to defend herself strenuously, and this act of affirmation (that generates an individual perspective) also involves a direct questioning of any external authority: Evans does not swear on the crucifix, because "a greater than the magistrate" commands her not to do so. Thus Evans' individuality is created dialectically in this text, through an open conflict with external forces, while being directly sustained by the voice of Christ as expressed in the Gospels.

Evans speaks in the first person every time she reports her separate interrogation at the hands of the inquisitors, or on the occasions when she reports her personal visions or inner conversations with the Spirit; on all other occasions, her perspective is merged with Cheevers', and expressed in the first person plural. This is what occurs in the third interrogation (this time, on matters of doctrine), when both women are questioned in depth on the specific aspects that differentiate their beliefs from those of the Catholic faith:

He asked, How we did believe the Resurrection? We answered, We did believe that the just and the unjust should arise, according to the Scriptures [...] He asked, if we believed in Purgatory? We said, No; but a Heaven and a Hell [...] He asked, if we believed 
their holy Sacrament? We said, We never read (the Word) Sacrament in Scripture. The Fryar replied, Where we did read in our Bibles Sanctification, it was Sacrament in theirs. He said, Their holy Sacrament was Bread and Wine, which they converted into the Flesh and Blood of Christ by the virtue of Christ. We said, they did work Miracles then, for Christ's virtue is the same as it was when it turned Water into Wine at the Marriage in Canaan. (Evans and Cheevers 1662:6)

This is a key episode, not only in terms of the women's confrontation with their captors, but especially because it sets the dominant pattern of voices and perspectives for the rest of the text. It should be noticed that Evans does not deem it necessary to distinguish between her own voice and Cheevers' when it comes to matters of doctrine (their answers in this text are always introduced by "we said"): it does not matter who actually voices the responses to the inquisitors, or which of the two women is speaking, as long as their doctrinal position is clear: they speak with the same accent. And that accent is in turn distinguished from the inquisitors': their doctrinal positions are also included at every point, and Evans is careful to reproduce their voices at length, so as to preserve a full sense of dramatic exchange, and to specify the doctrinal divergences at stake. ${ }^{5}$ We may have some doubt as to the exact accuracy of Evans's rendering of the inquisitors' voices (they probably did not state that they "converted" bread and wine into flesh and blood, for example), but her wish is to include the language of their adversaries, and to contrast it at every point with their joint perspective. The confrontation reproduced here is a clash of opposing voices, each of them poised against the other and developing over and against it; the typography of the 1662 edition of the text directly enhances this sense of dramatic contrast by presenting the voices of the inquisitor and of the two women in two alternative letter types (italics and roman, respectively), which oppose each other visually on the surface of the page (even the voice of the Spirit is distinguished by being printed in Gothic characters, and thus set apart from the dominant roman lettering: not an innocuous kind of differentiation, of course).

\footnotetext{
5 The question of reproducing the voice in the text is complicated further when we take into consideration the fact that some sentences by Evans and Cheevers throughout the whole text are borrowed directly from The Book of Common Prayer.
} 
Here it is important to pause and reflect for a moment on the canny appropriation and manipulation of the material conditions of textual production and publication in this tract. This text is addressed primarily to the Quaker communities, but it could also circulate beyond them: in any case, the reader first approaching it would necessarily notice the variety of fonts; a subseqent, more careful reading would reveal that, with only a few exceptions, the fonts (gothic, italics, and the dominating roman type) tend to classify and order the many voices of the text. In this way, the very material appearance of $A$ Short Relation becomes a part of its message, and cannot be disentangled from it. We cannot establish with any certainty, of course, where the decisions concerning the use of different fonts originated: whether Evans gave specific indications as to their use, or whether this was established exclusively by Robert Wilson, the printer, or by Baker; in fact, given the degree of closeness and collaboration between Evans and Baker, it is quite possible that the decisions about fonts were agreed on by both of them. In any case, what matters is the adaptation of the possibilities offered by print to the rich, multi-vocal interplay of the narrative: the physical characteristics of print, its stylistic dynamics, are harnessed to the religious impulse that drives the text.

Other voices are occasionally included as the narration proceeds: the voice of the English consul (who attempts to improve the situation of Evans and Cheevers), and those of the judges and the prison-keepers. In this way, the narration of the women's imprisonment integrates within itself a remarkable variety of accents, even though the dynamics of the text tend to reproduce similar patterns of dramatic confrontation, in which the women's language is opposed to that of their captors and the Catholic authorities. An external appearance of heteroglossia is thus created as the text progresses; however, it is unclear to what extent this text is really heteroglot in the Bakhtinian sense of the term.

The intensity of these exchanges increases as time goes by; after the first month of captivity, the women start a period of fasting in order to force their release or, if this should not be possible, to achieve martyrdom. At that point, Evans is once again separated from Cheevers, and a Dominican friar almost uses physical violence against her. The strong tension of the verbal exchanges is centred, in 
this occasion, on the use and significance of the crucifix, which comes close to being used as a weapon:

The Fryar commanded my dear friend to go out of the room, and he came and pulled my hand out of the bed, and said, is the devil so great in you, that you cannot speak? I said, Depart from me thou worker of iniquity, I know thee not; the Power of the Lord is upon me, and thou call'st him Devil. He took the Crucifix to strike me in the mouth, and I said, Look here! and I asked him, whether it were that Cross which crucified Paul to the World, and the World unto him? And he said, it was, I denied and said, the Lord had made me a Witness for himself against all workers of iniquity $\mathrm{He}$ bid me be obedient, and went to strike me: I said, Wilt thou strike me? He said he would. I said, Thou art out of the Apostles Doctrine, they were no strikers; I deny thee to be any of them who went in the Name of the Lord. (Evans and Cheevers 1662:10)

Here the crucifix becomes a sign over which opposing discourses are projected, and it acquires different connotations depending on who interprets and uses it. For Evans, the crucifix is not only a reminder of the passion and of Christ, but, very significantly, the same cross which brought about the crucifixion of Paul: for her, its sight awakens a sense of parallelism between herself and the first Christians, which reinforces her role as a disciple of Christ and a preacher of his doctrine. For the Dominican friar, on the contrary, the crucifix is a sign and guarantee of his own authority, a physical representation of the power of the church, and, as such, it can be used physically against heretics. The moment when the Friar tries to strike Evans for the second time marks the climax of this confrontation, but, even at this point, Evans can turn the tables on her captor, by making use of one of the essential tenets of Quakerism, the renunciation of all forms of violence: the apostles "were no strikers," and none that threaten others can number themselves among "them who went in the name of the Lord."

There is a final element that contributes to the differentiation of Evans' voice, even beyond her constant contact with the Spirit: the visions that she receives individually, in moments of crisis, and which are a major source of relief and comfort in her trouble. These visions occur only in specific moments, coinciding (perhaps intentionally) with periods of fasting, or of great physical deprivation. Fasting was a common form of active resistance for Quakers whenever they were deprived of freedom or put under 
institutional pressure, and Evans and Cheevers make use of it twice during their imprisonment. On the first occasion, after having fasted for several weeks, and having rejected the help of a physician that the inquisitors had sent to them (in exchange for their doctrinal recantation), Evans experiences a long and complex vision, which appears to have been sent to her as comfort in her time of need:

I saw a great wonder in Heaven, the Woman cloathed with the Sun, and she had the Moon under her feet, and a Crown of 12 stars upon her head, and she travelled in pain ready to be delivered of a Man-child, and there was a great Dragon stood ready to devour the man-child as soon as it was born; and there was given to the Woman two Wings of a great Eagle to carry her into the desert, where she should be nourished [...] And I heard another trumpet sounding in Heaven [...] and I heard a voice saying unto me, 积ehold And I looked, and I saw Pharaoh and his host pursuing the children of Israel, and he and his Host were drowned in the Sea. (Evans and Cheevers 1662:12)

This vision is, for the most part, nothing more than a reworking of key passages in chapter 12 of the Book of Revelation; the apocalyptic imagery here evokes the themes of persecution by the devil (through the key image of the woman crowned with stars and menaced by the dragon) and of confrontation between good and evil (in the final battle between angels and demons, at the end of time). To be sure, there is an implicit typological identification here: Evans and Cheevers are also living under persecution, and even in their imprisonment they are contributing to the arrival of the Final Judgement by participating in the war against the forces of evil. There is a further use of typology at the end of the passage, when Evans hears the trumpets that announce the drowning of Pharaoh and its hosts; here both women are implicitly identified with the people of Israel in their exile. Evans' visions are outstanding for their lack of sensory or physical detail; there is little in them that can be compared to the strong sensory quality we find in the writings of Catholic mystics, for example. On the contrary, the very substance of these visions is the text of Scripture, the word of God, remembered and re-experienced by the speaker in ways that establish implicit parallelisms between herself and the biblical figures and situations that she evokes. Interestingly, Evans herself is keenly alert to the textual basis of her visions; immediately after the passage quoted above she hastens to certify its authenticity, despite its evident dependence on the text of the Bible: 
Dear Friends and People, whatsoever I have written, it is not because it is recorded in the Scripture, or that I have heard of such things, but in obedience to the Lord I have written the things which I did hear, see, tasted and handled for the good Word of God, in praise of his Name for ever. (Evans and Cheevers 1662:1213)

In this way, the very language of Scripture is explicitly recognised by Evans herself as a key constituent of her own voice, and as informing and determining key areas of her perspective and identity. The word of God, then, is to be distinguished and privileged among all the other words that are heard in the text; it thus begins to be evident that the multi-vocality of the text does not open itself to a full heteroglossia, but rather relies on one single voice, that of the Lord (expressed either through Scripture or through the Spirit), as its ultimate source of authority and truth.

At this point, it should be possible to clarify the relationships that are established among the various voices speaking in the text, and to determine the hierarchies among them. In order to do so, I will analyse the multi-vocality of the narrative with the help of a representative section in its second half, at a key moment: the description of the second period of fasting voluntarily undergone by the two women. This situation occurs after several unsuccessful attempts at mediation by the English consul, and after the help of a physician has once again been rejected by the two women, whose physical decay is beginning to be evident to all. It is at that point that their fasting begins:

Then the Lord called us to fasting for eleven dayes together, but it was so little, that the Fryars came and said, that it was impossible that Creatures could live with so little meat, as they did see we did for so long time together; and asked what we would do? And said their Lord Inquisitor said, We might have anything we would. We said, We must wait to know the mind of God, what he would have us to do. We did not fast in our own Wills but in obedience to the Lord. They were much troubled, and sent us meat, and said the English Consul sent it. We could not take any thing till the Lord's time was come. We were weak, so that Sarah did dress her head as she would lye in her Grave, (poor Lamb) I lay looking for the Lord to put an end to the sad trial which way it seemed good in his sight. Then I heard a voice, saying, 嫼 shall not oye. [...] Our Enemies treated us kindly in a strange Land, said I. But we were afraid to eat, and cryed to the Lord, and said, We had rather dye, 
than eat any thing that is polluted and unclean. The Lord said unto me, Thou mayest as freely eat [...] Yet the Lord did work as great a Miracle by our preservation, as he did by raising Lazarus out of the Grave. [...] The Fryars did say, the Lord did keep us alive by his mighty power, because we should be Catholicks. We said, the Lord would make it manifest to us then; they should know the Lord had another end in it one day. (Evans and Cheevers 1662:2324)

The dominant perspective here is presented, as usual, as a shared one ("the Lord called us to fasting us for eleven dayes"); against this voice appear those of the Inquisitors, italicised, so as to be clearly demarcated, and presented in debate with the voices of the two women, and as opposed to them. There are a few moments when we notice that Evans' own voice is more clearly individualised: first, when she notices Sarah's preparation for death ("Sarah did dress her head as she would lye in her Grave, poor Lamb") and, second, in her direct exchanges with the voice of God, which speaks directly to her, and thus singularises her ("Then I heard a voice, saying, Ye shall not die"). After some food is offered to the women by their captors, a quote from the Psalms is introduced ("Our enemies treated us kindly in a strange land"): Scripture is thus woven into the text, and used as a perspective from which the situation can be interpreted. Biblical typology is also present in situational parallels with the beginnings of Christianity, so as to assert the direct intervention of God ("the Lord did work as great a miracle for our preservation, as he did by raising Lazarus from the grave"). In the end, the whole situation is only resolved when the voice of the Spirit authorises them to eat, through direct communication with Evans ("the Lord said unto me, Thou mayest as freely eat"). And even at that moment, after they have been saved and their fasting has ended, the situation is interpreted in contradictory ways by them and by the inquisitors; both interpretations are included, and contrasted with each other, at the end of the paragraph.

This episode can be taken as a telling example of the way in which the whole narrative works: as a story told by different voices presented in active interaction, but which do not have the same authority in the text. All of the voices are included and reproduced within the dominant, shared perspective of the authors, but the interpretative acts within the text, the occasions on which the 
situation is evaluated, tend to occur in the individualised voice of Evans when she hears the Lord speaking to her; and on these occasions it becomes evident that her own voice is entirely subordinated to that transcendent, superior authority. In this way, the whole variety of the voices in the text is subordinated to one single voice: that of the Spirit, which determines the actions of the women and validates their experience. That voice is in turn complemented by the various quotations from Scripture, which may be voiced by the Spirit or evoked by Evans, or which, alternatively, may be echoed in her visions.

Thus, a text that initially seems to offer a multiplicity of perspectives and a fluent multi-vocality reveals itself, in the final analysis, to be structured according to an underlying single purpose and unified perspective. Since $A$ Short Relation does not contain a variety of points of view on an equal basis, but offers one dominant viewpoint (Katharine Evans') and ultimately one basis of interpretation (furnished by the voice of the Spirit), and since the text does not display a real variety of styles coexisting equally in the same space, but a subordination of all these styles to the voice of God, it is safe to conclude that the text displays a vivid formal plurality, but one which does not open itself to a full heteroglossia. On the contrary: while its surface seems to offer a continuous exchange and interplay between different voices, a close stylistic analysis shows that this is only an appearance; it is the voice of the Spirit, speaking in the accents of Scripture, that is offered as the ultimate truth in the text, and as the ultimate basis for any interpretation of it.

\section{Gendering the Text: an Impossible Task?}

Some key elements of the early Quaker faith coincided with themes that had become popular in the radical agenda within the context of the English Civil War: Republicanism, communality and freedom of conscience. This latter aspect manifested itself in Quakerism as a complete lack of external religious authority, since spirituality was experienced there through personal contact with God (the "Inner Light"). Elaine Hobby has argued that "by the Revolutionary years, arguments used to justify intervention in public affairs by those men previously excluded from politics proved 
particularly adaptable to support the idea that women, too, could act" (2002:162); therefore, a large number of women could make the most of this opportunity to gain self-esteem and presence in the public arena. Still, readers in the twenty-first century are left wondering to what extent Evans and Cheevers (and, indeed, most women prophets from the period) were fully sensitive to gender issues, if at all. In this regard, Phyllis Mack reminds us that "a primary tenet of early Quakerism was that the hierarchical character of gender relationships, indeed of all social relationships, was a product of human sinfulness, an outcome of the original Fall from grace" (Mack 1992:140). We must therefore be ready to acknowledge the religious purpose behind the Quaker attempt at reaching for equality and communality and obliterating any sign of social status, including gender.

The new kind of freedom offered by Quakerism must have been attractive for many women, but not necessarily because of reasons directly related to their gendered identity. In their narration of captivity in Malta Evans and Cheevers can oppose Catholic authorities in a very powerful and convincing way, and even engage in direct communication with God: this empowers their faith and their authority, but seems to affect their condition as women only indirectly. Danielle Clarke invites us to distinguish between material conditions (in this case, the opening of new possibilities for women within radical and dissenter groups) and their effect upon the texture of a piece of writing; according to her, we cannot automatically appropriate those texts to serve the interests of feminism:

One might argue that in relation to the Renaissance, this needs to be taken a step further still: not only are most of the texts in question not feminist in any legible sense, they are also subject to a series of conditions and regulations which we do not always recognize. If these texts refuse to yield up feminism, it may also be the case that feminism, as it has been applied, does not yield up the texts. (Clarke 2000:7)

But even if we cannot read $A$ Short Relation with a feminist agenda in mind, it is still possible to examine it in detail to see what kind of gender discourse is articulated within it. For example, gender concerns seem to be only secondary during the first confrontations between the two women and the inquisitors. Being women, of course, they are first made to identify themselves in terms of the 
families to which they belonged ("they asked us our names, and the names of our husbands"), but the interrogations quickly come to be focused on matters of doctrine, and other aspects are temporarily forgotten. It is only after the two women make use of active forms of resistance (such as fasting) that the accusations and reactions against them begin to show signs of misogyny; in the second half of the narrative, Evans is called a "madwoman", a "possessed one" and, eventually, a "witch" (twice). None of these terms, however, awaken any strong response from her (as we have seen, she only reacts energetically when matters of faith are at stake). There are occasional hints of a more purposeful gender differentiation when an apparently friendly Dominican friar tries to persuade the women to convert, and starts addressing them as "good women;" in contrast, and unsurprisingly, Evans immediately hears the voice of God designating herself and Cheevers as "daughters of Sion:"

He then did say, We were good Women, but yet there was no redemption for us, except if we would be Catholicks. Now the Lord said, Fear not, Daughters of Sion, I will carry you forth as Gold tryed out of the fire. And many precious promises did the Lord refresh us with, in our greatest extremity [...] And the Lord said, fear not Daughter of Sion, ask what thou wilt, and I will grant it thee. (Evans and Cheevers 1662:34)

In itself, this does not go beyond an act of re-naming, through which Evans can cast herself and Cheevers into a more heroic role than that simply of "good women." Later on, when several attempts are made to force Evans to convert to Catholicism, she thinks her enemies are trying to lead her to a renunciation of her beliefs by treating her more courteously:

I cannot expresse the large love of our God, how he did preserve us from so many deaths and threatenings, as they did come to me with falling upon their knees, saying Miss, and would have me to say after them, but in the Name of the Lord I denied them. (Evans and Cheevers 1662:37)

On another occasion, one of the friars tries to force Evans to perform some kind of practical work to occupy her time in prison; Evans states that she is quite capable of writing, and at that point it becomes evident that Quaker culture has trained her in forms of intellectual activity (in the service of faith) that do not fit Catholic perceptions of women's work. After this exchange, Evans' capacity for work is redirected towards more traditionally feminine 
occupations, and both she and Cheevers end up repairing the clothes of other prisoners:

The Fryar then came to me, and askt me, why I did not work? I said unto him, What Work dost thou do? He said he did write. I told him I would write too, if he would bring me a Pen, Ink and Paper, and I would write truth. He said, He would not that we should write, for St. Paul did work at Rome, and we might get nine or ten grains a day, if we would knit, that is three half pence [...] Then his mouth was stopped, and he spake no more to me of work: But though our affliction of body was great, and our travel of soul was greater, yet we did knit Stockins, and gave to them that were made serviceable to $u$., and did make Garments for the poor prisoners, and mended their Clothes which had need, and were made helpful to them all. (Evans and Cheevers 1662:41-42)

In this way, in the Maltese prison, and under the supervision of Catholic authorities, two women who are used to reading and writing have to turn to more conventional forms of work. The absence throughout the text of any sense of female inferiority is remarkable. In the seventeenth century, dominant religious ideology (whether protestant or Catholic) established a solid identification between woman and sin, and tended to see the very image of woman as symbolising the flesh, temptation or sinfulness. These connotations are conspicuously absent from the writings of Evans and Cheevers: at no point do they seem to have any perception of negative connotations of their gender, not even at a symbolic or figurative level. Their use of biblical language tends, if anything, to reinforce this impression. The religious figures they compare themselves with are the apostles, the first Christians (most notably St. Paul), Old Testament patriarchs and prophets (Daniel, David, and Jonah) or Christ himself: the typological referents involved in the text are almost uniformly male, and the women see these referents as valid elements of self-identification. There are almost no typological identifications with female figures (a notable exception being the image of the woman crowned with stars, in Evans' vision); the two women see themselves as empowered prophets and preachers, as fully authorised as the ancient patriarchs, irrespective of their condition as women.

The personal letters Daniel Baker added to A Short Relation in the second printing of the narrative in 1663 are relevant here. Although we might be tempted to suspect some modification of 
these texts by Baker, it is unlikely that this actually happened: in early Quakerism, epistle writing was very often used to strengthen the bonds among Friends living in distant communities. Letters written and sent from one Quaker community to another could therefore come to perform a double function, as private documents (from one family member to another) and as public texts (meant to be read in public, as examples of perseverance and endurance, and as having doctrinal content). In this context, letters written by women could easily become a textual space for freedom: according to Margaret Ezell, women could find in letters a space "through which to express their anger at the wrongs suffered at the hands of contemporary society and their loyalty to the beleaguered flock" (Ezell 1993:142). For example, we find the voice of Katharine Evans, addressing herself to her husband and children, in a letter written "in the Inquisition in Malta, in the eleventh month of the year 1661:"

Most dear and faithful Husband, Friend and Brother, begotten of my Eternal Father, of the immortal Seed of the Covenant of Light, Life and Blessedness, I have unity and fellowship with thee day and night, to my great refreshment and continual comfort, praises, praises be given to our God for evermore, who hath joined us together in that which neither Sea nor Land can separate or divide. (Evans 1662:53)

Evans' husband is for her also a "Friend and Brother," a member of the same religious community to which she belongs and, to the extent that he is also "begotten of my eternal Father," her equal. This initial address involves references to their union despite their present physical division by "sea or land," but it is in the following paragraph that this subject is fully discussed:

My dear heart, my soul doth dearly salute thee, with my dear and precious Children, which are dear and precious in the Light of the Lord, to thy endless joys, and my everlasting comfort, glory be to our Lord God eternally, who hath called you with a holy Calling, and hath caused his Beauty to shine upon you [...] My dear hearts, the promises of the Lord are large, and are all Yea and Amen to those that fear his Name; he will comfort the mourners in Sion, and will cause the heavy-hearted in Jerusalem to rejoice, because of the glad tidings [...] In our deepest affliction, when I looked for every breath to be the last, I could not wish that I had not come over Seas, because I knew it was my Eternal Father's Will to prove me. (Evans 1662:53) 
Evans salutes her husband and remembers her children, but above all she reminds him of the "calling", that is, the religious mission that has been imposed on him as well as on her. The references to her difficult position at the hands of the Inquisition are introduced by typological references to the sufferings of Israel; and, when her serious plight in Malta is finally discussed ("our deepest affliction"), there is no hint of any desire to return home before completing the mission, or to substitute the pains of prison for the life of a housewife: on the contrary, the pain that Evans experiences in her imprisonment is to be celebrated as signifying "my eternal Father's will to prove me."

A second letter by Katharine Evans is even more explicit. After saluting her husband, somewhat more directly than on the previous occasion ("Dear husband, with my dear children, I beseech you together to wait in patience"), Evans goes on to express her longing for her family:

I have been very sensible, dear Husband of thine, and our Children, and many dear friends more, of your sorrowful souls, mourning hearts, grieved spirits, troubled minds for us, as being Members of one body, Christ Jesus being our Head, we must needs suffer together, that we may rejoice together [...] Though we are absent in body in the Will of God, from you, yet we are present in Spirit in the Will of God, with you, and we do receive the benefit of all your prayers daily, and do feel the Springs of Life that do stream from all the faithful hearted, to our great refreshment and strengthening. (Evans 1662:61)

There is a clearer sense of longing and of anticipation of a family reunion here; language has become more affective and more expressive of closer personal bonds. Evans' husband and children, however, are regarded as part of a wider community ("many friends more"), within which the family is firmly rooted. Both husband and children are evoked as part of an identity that is solidly fixed in the heart of a living and active social network, with Christ himself the head, and within which the work of preaching (and the need to suffer) are seen as essential aspects of self-definition. For Evans, as for so many other Quaker women, being a mother or a wife is not perceived as being in contradiction to that of a preacher (or, eventually, a martyr): on the contrary, her family has to accept her separation from them as part of the service to God that binds them together. Evans' active role in the world and her sense of her own 
worth are legitimised by her social environment, and created within it: Quaker doctrine, and Quaker society, have enabled her to see her mission and activities as being as valid as a man's.

It seems safe to conclude, then, that the absence of a negative sense of the feminine in A Short Relation is, to some extent, the result of the authors' socialization in a community that prided itself on notions of equality. It may seem paradoxical from a twenty-first century perspective, but the strength and confidence with which these women carried out their preaching mission were not opposed to, but based on, their role as wives and members of a strongly selfconscious social group. Evans and Cheevers were able to move beyond the limitations of gender distinction not by overcoming these differences, but simply by ignoring them: an attitude that was firmly rooted in their immediate social milieu.

\section{Conclusions}

There is now a solid scholarly consensus ${ }^{6}$ that the corpus of early Quaker women's writing can help us to trace the beginnings of female voices in literature, as well as early notions of female selfhood. Quaker women belonged to a community that empowered them spiritually, and within that community they formed a subgroup which, because of their religious commitment, could go beyond traditional definitions of gender identity. According to Elaine Hobby, "what is evident from this sample of visionary prophets is both that the role of prophet could give a woman access to an audience for her views, and that the question of her gender was always an issue for those who received her message" (Hobby 2002:269). In A Short Relation we see how Evans' and Cheevers' beliefs empower them spiritually, and how their communication with the Spirit allows a powerful first person singular (and a first person plural) to materialise, opposing voices of male authority.

A Short Relation offers a vivid, dynamic interplay between different voices; it reproduces and integrates contradictory approaches to reality and to religious doctrine. However, as we have seen, close analysis reveals that this seeming variety does not imply an open or (in Bakhtinian terms) a polyphonic perspective: what we

${ }^{6}$ See footnote 5 , above. 
have here is multi-vocality, but not heteroglossia. It is above all the voice of the Spirit that is asserted and recognised in this text, and it is that voice which is presented (both thematically and typographically) as having a pre-eminent authority over all the others. The identity of Katharine Evans is created dynamically in the text, and it is clearly differentiated from that of Sarah Cheevers, in two ways: first, through the constant dialectic exchange between Katherine's voice and those of the male authorities that she opposes, and secondly, through her personal, close interaction with the voice of the Spirit. Identity is thus created here both through a submission and a defence of a religious position and through an intimate sense of exchange with the voice of God, which in the text is presented as speaking to Evans in the accents of the Bible. It becomes evident that their imperviousness to misogyny does not come from a genderconscious attitude but from their religious convictions, which, for them, supersede all forms of institutional or legal constraint. Therefore, A Short Relation and its idiosyncratic interplay of voices creates an identity which goes beyond gender effacement or plain submission to God. This Quaker emphasis on engaging in communication with God, on being one with Him "in the Light" (as Quaker terminology put it), is, however, complemented by various other perspectives and approaches in A Short Relation. The voices and accents of the inquisition and the Catholic authorities are also fully acknowledged and integrated in the text, and they are contrasted at every point with those of the protagonists; even the voice of the Spirit is heard in the text, offering guidance and support to the two women. They echo God's concerns with the contemporary state of affairs and they display rhetorical skills which go beyond the written and the uttered word to be re-enacted in public. When poststructuralist scholars like Christina Berg and Philippa Berry focus almost exclusively on the rhetorical strategies employed by prophetesses, considering that they "represented their own sexuality within a discursive medium where an explicitly political content was subsumed within a highly personalized mode of expression" (Berg and Berry 1981:38), they recognize that the rhetorical power of prophetic speech in the seventeenth century went beyond the content of the words themselves and that it was the interaction between the Biblical message and its various appropriations by female prophets that transformed prophetic writing into a rich locus of study. 


\section{References}

Bakhtin, Mikhail 2006 (1981). "From the Prehistory of Novelistic Discourse." Ed. Michael Holquist. The Dialogic Imagination, Four Essays. Austin: University of Texas Press: 40-81.

Berg, Christina and Phillipa Berry 1981. "Spiritual Whoredom: An Essay on Female Prophets in the Seventeenth Century." Ed. Francis Baker. 1642: Literature and Power in the Seventeenth Century. Colchester: University of Essex Press: 39-54.

Besse, Joseph and Michael Gandy eds. 2003. Sufferings of Early Quakers: Ireland, Scotland and Wales Including Monmouthshire and Shropshire 16531691 Vol 5. London, Sessions Book Trust (facsimile edition).

Biddle, Hester 1660. A Warning from the Lord God. London: Robert Wilson.

Clarke, Danielle 2000. "Introduction." Eds. Danielle Clarke and Elizabeth Clarke. 'This Double Voice': Gendered Writing in Early Modern England. London: Macmillan Press: 1-15.

Coles, Kimberly Anne 2008. Religion, Reform, and Women's Writing in Early Modern England. London: Cambridge University Press.

Crawford, Patricia 1993. Women and Religion in England 1500-1720. London: Routledge.

Evans, Katharine and Sarah Cheevers 2001 (1662). This is a Short Relation of some of the Cruel Sufferings (for the Truths Sake) of Katharine Evans E Sarah Cheevers in the Inquisition in the Isle of Malta. London: Robert Wilson. Facsimile edition: The Early Modern Englishwoman: A Facsimile Library of Essential Works. Eds. Betty S. Travitsky and Patrick Cullen Series II, Printed Writings, 1641-1700: Part I, Vol. I, Life Writings I. Aldershot: Ashgate.

Evans, Katharine and Sarah Cheevers (1663). A True Account of the Sufferings of Katherine Evans and Sarah Cheevers. (London: Robert Wilson). Facsimile edition in Early English Books Online http://eebo.chadwyck.com/home. Copy from Haveford College Library, wing 2220:03).

Fell, Margaret 1660. A Declaration and an Information from us the People of God Called Quakers. London: Thos. Simmons \& Robt. Wilson.

Feroli, Teresa 2006. Political Speaking Justified: Women Prophets and the English Revolution. Newark: University of Delaware Press.

Gill, Catie 2005. Women in the Seventeenth-century Quaker Community: A Literary Study of Political Identities, 1650-1700. London: Ashgate Publishers.

Gill, Catie 2009. "Evans and Cheevers's A Short Relation in Context: Flesh, Spirit, and Authority in Quaker Prison Writings, 1650-1662." Huntington Library Quarterly 72/2: 257-272. 
Graham, Elspeth 1989. Her Own Life: Autobiographical Writings by SeventeenthCentury Englishwomen. Eds. Hilary Hinds, Elaine Hobby, and Helen Wilcox. London: Routledge.

Gillespie, Katharine 2004. Domesticity and Dissent in the Seventeenth Century: English Women's Writing and the Public Sphere. Cambridge: Cambridge University Press.

Gray, Catharine 2007. Women Writers and Public Debate in $17^{\text {th }}$-Century Britain. New York: Palgrave.

Hinds, Hilary 1996. God's Englishwomen: Seventeenth-century Radical Sectarian Writing and Feminist Criticism. Manchester: Manchester University Press.

Hobby, Elaine 2002. "Prophecy." Ed. A. Pacheco. A Companion to Early Modern Women's Writing. Oxford: Blackwell Publishers: 264-282.

Holquist, Michael 2005. Dialogism. London: Routledge.

Knott, John Ray 1993. Discourses of martyrdom in English literature, 1563-1694. Cambridge: Cambridge University Press.

Longfellow, Erica 2004. Women and Religious Writing in Early Modern England. London: Cambridge University Press.

Malcomson, Cristina and Miholo Suzuki 2002. Debating Gender in Early Modern England 1500-1700. New York: Palgrave.

Mack, Phyllis 1992. Visionary Women: Ecstatic Prophecy in Seventeenth-Century England. California: University of California Press.

Punshon, John 2006 (1984). Portrait in Grey: a Short History of the Quakers. London: Quaker Books.

Purkiss, Diane 1992. "Producing the Voice, Consuming the Body: Women Prophets of the Seventeenth Century." Eds. Isobel Grundy and Susan Wiseman. Women, Writing, History 1640-1740. London: Batsford: 139-158.

Trill, Suzanne, Kate Chedgzov, and Melanie Osborne, eds. 1997. Lay by your Needles, Ladies, Take the Pen: Writing Women in England 1500-1700. New York: Hodder Arnold.

Wiseman, Susan 1992. "Unsilent instruments and the devil's cushions: authority in seventeenth-century women's prophetic discourse." Ed. Isobel Armstrong. New Feminist Discourses. London: Routledge: 176-196.

How to cite this article:

Font Paz, Carme. "II have written the things which I did hear, see, tasted and handled': Selfhood and Voice in Katherine Evans' and Sarah Cheevers' A Short Relation of Their Sufferings (1662)." SEDERI 20 (2010): 27-56.

Author's contact: Carme.Font@uab.cat

Submission: 31/10/2009

Acceptance: 21/02/2010 